\title{
加齢による聴力損失を考慮した変動騒音下における音声聴取成績 および音声の聴き取り易さに対する一予測手法*
}

\author{
為末隆弘**，佐伯徹郎**
}

\begin{abstract}
The authors propose a method for estimating and/or predicting the listening score and psychological impression of speech audibility taking into account an effect of the hearing loss due to aging under fluctuating noise. In a real acoustic environment in which audio signals are transmitted and listened to, both the sound pressure level and the frequency component of the noise show an irregular fluctuation over time. Taking the above into consideration, the index of $I$ which reflects the mutual relationships between the spectrum level of the speech peaks and that of the noise within a short time scale, is introduced. Prediction accuracy of $I$ is estimated, regarding how the listening score and psychological impression of speech audibility change in the case of listening to monosyllables under an actual noise environment. The predicted results are in good agreement with the observed values from psychological listening experiment that both the audio signal and the noise which passed through frequency filters simulating hearing loss due to aging are transmitted to subjects with normal hearing.
\end{abstract}

騒音の音圧レベル值および周波数構成ともに時々刻々と不規則に变動する実生活環境音場において音声を 聴取している場合の音声聴取成績および音声の聴き取り易さに関する心理的印象を，加齢による聴力損失特 性を考慮して予測するための一手法を提案したものである．具体的には，音声と騒音の振幅・周波数特性に 関する相対的関係を短時間スケールで捉えるための新たな指標 $I$ 導入し，現実的な音環境下で単音節音声 を聴取している場合の音声聴取成績打よび音声の聴き取り易さに関する心理的印象の予測問題について考察 している. 加齢による聴力損失を模擬した周波数フィルタに音声と騒音を通過させることにより模擬難聴状 態を実現し，模擬難聴状態の健聴者による音声聴取心理実験を行った結果，得られた実測データと予測結果 の間にほぼよい一致性が認められた。

(キーワード : 不規則変動騒音, 単音節, 音声聴取成績, 聴き取り易さ, 予測, 聴力損失)

\section{1.はじめに}

音声を伝達・聴取する現実の場においては，様々な騒 音が存在するのが常である。この場合, 聴取者が騷音に 悩まされることなく，音声の聴取に専念できる快適な音 環境を実現することが重要である，明瞭な音声を聴取で き，心理的にも快適な音場を設計する（例えば外来騒音 低減のための効率的な遮音材の選定や音声信号の音量調 節など）ためには，音声と騒音の振幅・周波数特性に関 する相対的関係と音声をどの程度正確に聴き取れるかと いった音声聴取成績やそのときの音声の聴き取り易さに

\footnotetext{
*受付：2008年12月4日＼cjkstart受理：2009年8月6日

**山口大学

Yamaguchi University
}

関する心理的印象との関連性を定量的に事前に把握して おくことが重要である，我々はこれまで，様々な騒音下 で音声を聴取している場合の音声聴取成績および音声の 聴き取り易さに関する心理的印象を推定・予測するため のいくつかの手法について考察した ${ }^{1 \sim 6)}$.これらの手法を 用いた場合には，従来より提案されている明瞭度指数 ${ }^{7)}$ や会話妨害レベル8) 等の評価指標を用いた場合に比べて, 音声聴取成績や音声の聴き取り易さに関する心理的印象 を共通に精度良く予測できることを確認した。

他方，人間の聴力は年齢とともに次第に低下していく ことが知られており，加齢に伴う聴力損失に関する周波 数特性が報告されている ${ }^{9 \sim 13)}$. さらに，加歯による聴力 低下が音声伝達に与える影響について，年齢や聴力レべ ルと明瞭度 ・了解度等との関係が多くの研究者によって 調査されている ${ }^{14 \sim 18)}$ 。しかしながら，加齢に伴う聴力損 失を考慮して，騒音下における音声聴取成績と音声の聴 
き取り易さに対する心理的印象を同時に推定しようとす る試みは行われていない。このような観点から既発表の

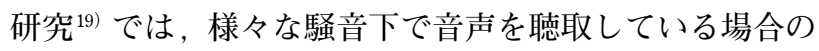
音声聴取成績や音声の聴き取り易さに関する心理的印象 を，加齢の聴力損失に関する周波数特性を考慮して推 定・予測するための一手法について考察した。しかし上 記の研究は, 騒音を音圧レベル值・周波数構成ともに時 間的変化のない定常騒音に限定して考察したものである。

音声を伝達し聴取する現実の音場では, 騒音の音圧レ ベル值打よび周波数構成ともに時々刻々と不規則に変動 しており，定常騒音下を対象としたこれまでの手法をそ のまま適用することは合理的でないと思われる。これま でにも, 変動騒音下に打ける明瞭度 ·了解度の予測手法 が提案されており 20 22), 我々もまた, 遮音対策実施前後 の音声聴取成績や音声の聴き取り易さに関する心理的印 象を予測するための手法について考察しているが ${ }^{23)}$, 加 齢による聴力損失を考慮して不規則変動騒音下に打ける 音声聴取成績や音声の聴き取り易さに関する心理的印象 を評価する試みはこれまでなされていない．

以上を踏まえて本論文では, 任意の不規則変動騒音下 で音声を聴取する場合の音声聴取成績および音声の聴き 取り易さに関する心理的印象を，加齢による聴力損失特 性を考慮して予測するための一手法を提案するものであ る. 具体的には, 音声と騒音の振幅・周波数特性に関す る相対的関係を短時間スケールで捉えるための新たな評 価指標を導入し，現実的な音環境下で単音節を聴取して いる場合の音声聴取成績および音声の聴き取り易さに関 する心理的印象の予測問題について考察する。聴覚末梢 系の老化には, 最小可聴值の上昇や周波数選択性打よび 時間分解能の低下，ラウドネス補充現象など様々な現象 があるが，本論文では特に最小可聴值の上昇に着目し， この現象を音声と騒音を周波数フィルタに通過させるこ とにより健聴者で模擬する方法を用いる。模擬難聴状態 に置かれた健聴者による音声聴取心理実験を行った結果, 予測結果と音声聴取心理実験による実測データとの間に ほぼ良い一致が認められた。

\section{2. 評価指標の導入}

既発表の研究1 6) では, 定常騒音下で単音節・単語音 声を聴取しているときの音声聴取成績および音声の聴き 取り易さに関する心理的印象を説明するために，指標 $S$ が有効であるとの知見を得ている．Sは次式で定義され ている.

$$
S=\sum_{i=1}^{8} a_{i}\left[L_{S_{\max }}\left(f_{i}\right)-L_{N}\left(f_{i}\right)\right]
$$

ここに $L_{S_{\max }}\left(f_{i}\right)$ は中心周波数 $f_{i}\left(f_{1}=63, f_{2}=125, \cdots, f_{8}=\right.$ $8000 \mathrm{~Hz}$ ) の各1/1オクターブ帯域における音声の最大音 圧レベル值である（明瞭度指数のオクターブバンド法? に打ける音声ピークスペクトルに相当する)， $L_{N}\left(f_{i}\right)$ は才 クターブ帯域における騒音の音圧レベル值である。また， $a_{i}(i=1,2, \cdots, 8)$ は音声了解に等しく寄与する 200 周波数帯域 8 が各オクターブ带域内に含まれる割合を考 慮して算出した重みであり，具体的には次のような值で ある。

$$
\begin{array}{llll}
a_{1}=0.00 & a_{2}=0.00 & a_{3}=0.06 & a_{4}=0.14 \\
a_{5}=0.23 & a_{6}=0.32 & a_{7}=0.23 & a_{8}=0.02
\end{array}
$$

上記のように，音声ピークスペクトルと定常騒音のスペ クトルからひとつの尺度值を求めることによって, 騒音 下での音声聴取成績および音声の聴き取り易さに対する 心理的印象を共通に推定・予測することができる ${ }^{1 \sim 6}$. さ らに既発表の研究19) では，加齢に伴う聴力損失に関する 周波数特性を考慮した場合の指標 $S$ と音声聴取成績およ び音声の聴き取り易さに関する心理的印象との関係を求 めた。これらの結果をそれぞれ図1および図 2 に示す。横 軸は $S$ を, 縦軸は聴取成績 $t$ おひび聴き取り易さに関する 心理的印象 $A$ を表し， $S$ が大きなるほど，聴取成績が良 好であり，聴き取り易いことを表している。また両図中 の $20 \mathrm{~s} ， 50 \mathrm{~s} ， 70 \mathrm{~s} ， 80 \mathrm{~s}$ は，それぞれ $20 ， 50 ， 70 ， 80$ 歳 代の加齢による聴力損失を考慮した場合の結果を表して いる。しかしこれらは騷音を音圧レベル值・周波数構成 ともに時間的変化のない定常騒音に限定して考察された ものであり，現実の不規則変動騒音下に上記の手法をそ のまま適用することは合理的でないと思われる。

上述のような観点から本論文では，実生活環境音場に おける音声聴取成績および音声の聴き取り易さに関する 心理的印象を評価するために，音声と騒音の振幅・周波 数特性の相対的関係を短時間スケールで捉えるための指 標として，これまでに提案した（1）式の指標 $S$ 基にし て，次の指標を導入する.

$$
I=\sum_{i=1}^{8} a_{i}\left[L_{S_{\max }}\left(f_{i}\right)-L_{N_{p}}\left(f_{i}\right)\right]
$$

上式の $a_{i}$ および $L_{S_{\max }}\left(f_{i}\right)$ は $(1)$ 式と同じものである が, $L_{N_{p}}\left(f_{i}\right)$ は騒音の各1/1オクターブ帯域音圧レベルの瞬 時值である。ここでは，あくまでも現実的な環境騒音と の関連性に重点を置きながら音声聴取成績および音声の 聴き取り易さに関する心理的印象を考察しようとしてい ることから, $L_{N_{p}}\left(f_{i}\right)$ は騷音測定機器の実効值検波回路の 

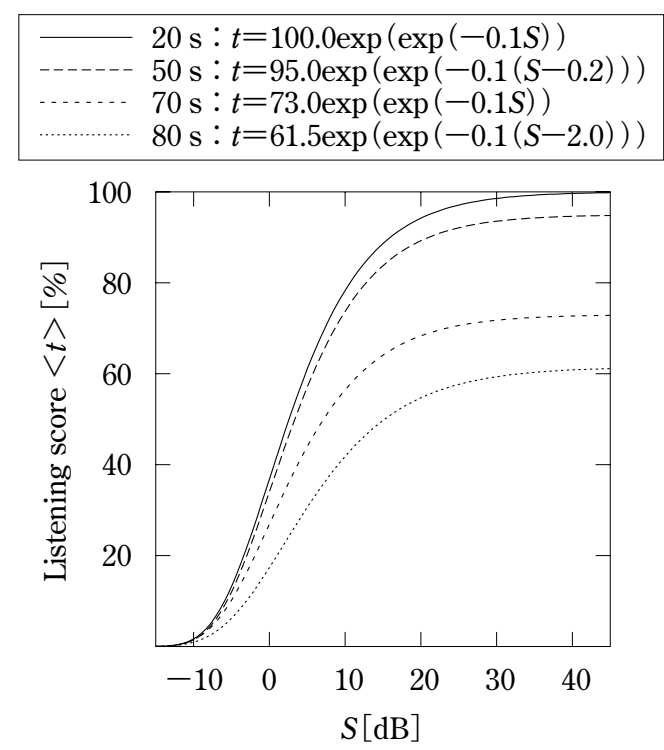

図1 指標 $S$ と音声聴取成績の関係 19

Fig. 1 Relationships between $S$ and $<t>{ }^{19}$.

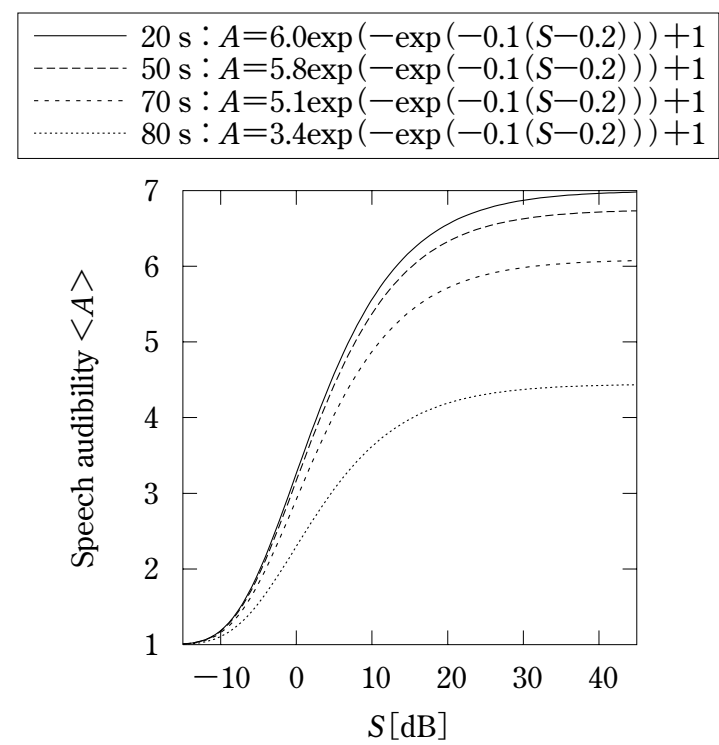

図2 指標 $S$ と音声の聴き取り易さに関する心理的印象の関係 ${ }^{19}$

Fig. 2 Relationships between $S$ and $<A>{ }^{19)}$.

時定数FASTにおおよそ相当する時間長で算出する。ただ し, 明瞭度指数オクターブバンド法7) と同様に, $L_{S_{\max }}\left(f_{i}\right)$ および $L_{N_{p}}\left(f_{i}\right)$ が健聴者の連続スペクトル音に対する最小 可聴レベル $L_{\text {min }}($ 図3の破線) 7) を下回る場合には，それ ぞれに指標算出のための下限値として $L_{\text {min }}$ を用いることと した。

\section{3. 音声聴取心理実験の概要}

この実験は, 聴力損失を模擬した場合の不規則変動騒 音下に打ける音声聴取成績や音声の聴き取り易さの心理

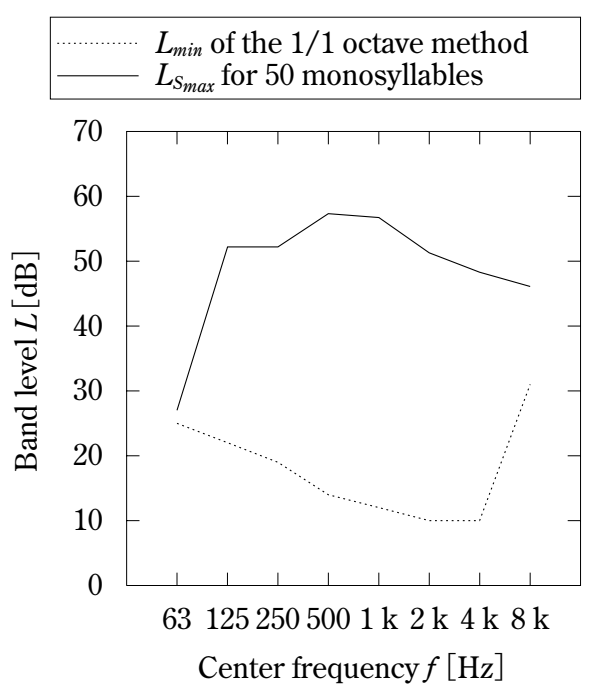

図3音声ピークスペクトルと指標算出のための最低音圧レ ベル

Fig. 3 Speech peaks and minimum levels for caluculation of the index.

的印象を実測し，予測值と比較するものである.

\section{3-1. 実験場所}

縦 $3.0 \mathrm{~m} \times$ 横 $3.0 \mathrm{~m} \times$ 高さ $1.9 \mathrm{~m}$ の容積をもつ無響室で行 った。暗騒音の音圧レベルは約 $36 \mathrm{~dB}$ （A特性音圧レベル では $21 \mathrm{~dB}$ (A) 程度) であった。

\section{3-2. 被験者}

聴力正常な 20 歳代の男子学生 20 名, 女子学生 4 名の計 24名であった。

\section{3-3. 掲示音}

\section{3-3-1. 音声信号}

補聴器適合評価用 CD（TY-89） ${ }^{24)}$ に収録されている単 音節語表の50音節をランダムに配置して作成した音源を 再生した．音源に対する周波数分析を行い，50音節（約

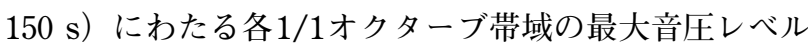
值を算定して，音声ピークスペクトルを求めた。さらに， このオーバーオール音圧レベル值が被験者の耳の位置で 約 $62 \mathrm{~dB}$ となるようにゲインを調整した。 ゲイン調整後の 音声ピークスペクトルを図3の実線で示す.

\section{3-3-2. 外来騷音}

音圧レベル值・周波数構成ともに不規則に変動する現 実的な騒音として, 以下の3種を採用した。

（a）非定常道路交通騒音: 交通流状態が非定常な交差点 付近の道路騷音を実際に道路端で収録したものを再 生して用いた。

(b) 定常道路交通騒音：Audio/Acoustics Technical $\mathrm{CD}^{25}$ 


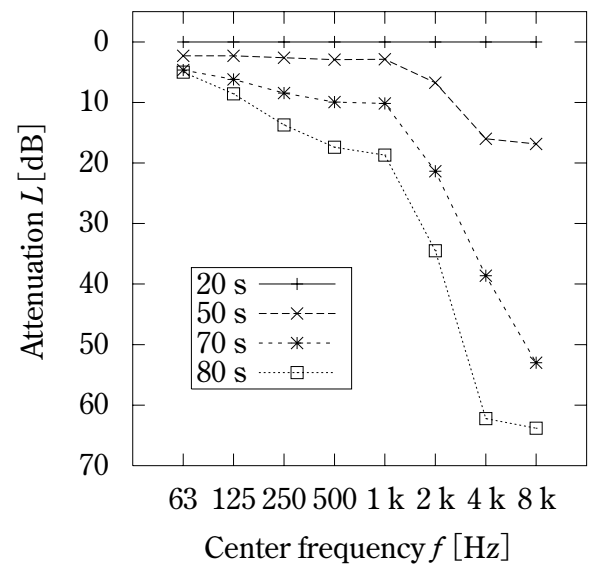

図4 聴力損失を模擬した周波数フィルタの特性

Fig. 4 Frequency characteristics of a filter simulated hearing loss.

に収録されている交通流状態が定常な道路交通騒音 を用いた。

(c) 航空機騒音：Audio/Acoustics Technical CDに収録さ れている航空機の離陸時の騒音を用いた。

上記の各騒音に対して, 時間平均音圧レベル值が 62 , $67 \mathrm{~dB}$ になるようした。これらのレベル值は現実的な騒 音の音圧レベルの一例として位置付けたものであるが， 予測手法の妥当性を検討する目的から，ある程度良好な 聴取成績が得られる条件下のみでなく, 音声の聴取がか なり困難となる条件下まで想定したものである.

さらに, 次の場合も検討した。

(d) 外来騒音なし

聴覚末梢系の老化による現象は, 最小可聴值の上昇の みでなく, 周波数選択性や時間分解能の低下, ラウドネ ス補充現象などがあり, 総合的に聞こえに影響すると思 われるが, 良質な騒音対策を施すためには個々の要因が どの程度影響を及ぼしているのかを検討しておく必要が ある。本論文では, 最小可聴值の上昇に着目し, 健聴者 で模擬する方法を用いる。これに関して，マスキングノ イズを用いる方法 ${ }^{26)}$ も検討されているが, 本論文では既 発表の研究 ${ }^{19)}$ と同様, 聴力損失の周波数特性を考慮して, 上述の音声と騷音を図 4 に示す 4 種類の周波数フィルタ $20 \mathrm{~s} ， 50 \mathrm{~s} ， 70 \mathrm{~s} ， 80 \mathrm{~s}$ に通過させた音源を作成した。 $20 \mathrm{~s}$, $50 \mathrm{~s}, 70 \mathrm{~s}, 80 \mathrm{~s}$ の順に, レべルを低下させるとともに高 周波数成分を大きく減衰させている. これらの特性はそ れぞれ，20，50，70，80歳代の20歳代を基準とした加歯 による聴力損失を表している ${ }^{11)}$. 作成した音源は, 騒音 条件： 7 種（騒音：3種 $\times$ 時間平均音圧レベル： 2 種十騒 音なし) X周波数フィルタ： 4 種の計 28 種である.

\section{3-4. 測定方法}

2本のスピーカから音声と騒音をミックスしたものを同 時に放射した。スピーカから約 $2 \mathrm{~m}$ 離れた位置に 4 名の被 験者が座り，聴取した単音節を記録紙に記入した。被験 者の位置によって提示音の音圧レベル值および周波数特 性に差異がないことを事前に確認した。ささらに, 既発表 の研究 ${ }^{19)}$ と同様, 音声に対してどのような心理的印象を もったかを次の七つにカテゴリー化された心理的評価尺 度 $\left(A_{1}\right.$ : 非常に聴き取りにくい, $A_{2}$ ：かなり聴き取りに くい, $A_{3}$ : やや聴き取りにくい, $A_{4}$ : どちらともいえな い, $A_{5}$ : やや聴き取りやすい, $A_{6}$ ：かなり聴き取りやす い, $A_{7}$ : 非常に聴き取りやすい) ${ }^{27)}$ により調べた。

\section{4. 音声聴取成績と心理的印象の予測}

騷音の音圧レベル值・周波数構成がともに不規則に変 動する現実の音場では，（3）式で定義されるIは確率変数 となる. 本論文では, 客観的かつ定量的に把握できるIの 確率密度関数 $p(I)$ と, Iを説明变数とした音声聴取成績 および音声の聴き取り易さの心理的印象に対する回帰関 数 $f_{t}(I)$ および $f_{A}(I)$ を用いて, 音声聴取成績の平均值 $<$ $t>$ おび音声の恥き取り易さに関する心理的印象の平均 值 $<A>$ を次式により予測する.

$$
\begin{aligned}
& <t>=\int_{D} f_{t}(I) p(I) d I(D=[-15,30] \mathrm{dB}) \\
& <A>=\int_{D} f_{A}(I) p(I) d I(D=[-15,30] \mathrm{dB})
\end{aligned}
$$

ここでは実用的な観点から，上式の $f_{t}(I)$ および $f_{A}(I)$ と して, 従来の研究19) で得られた $f_{t}(S)$ (図1）および $f_{A}(S)$ （図2）を採用した。

\section{4-1. 20 歳代健聴者の場合}

音声聴取成績および音声の聴き取り易さに関する心理 的印象の平均值を (4) 式および (5) 式で予測するために は, $p(I)$ を求めておく必要がある. まず, 各騒音の音源 を周波数分析して約 $0.1 \mathrm{~s}$ (騒音測定機器の実効值検波回 路の時定数FASTにおおよそ相当する時間長）ごとに $1 / 1$ オクターブ帯域音圧レベルを求めた。 この結果と罒3の音 声ピークスペクトルを用いて（3）式からIを算出し, その 確率分布 $p(I)$ を求めた. これらの結果の例として, 騒音 が（a），(b)，(c）（いずれも62 dB）の場合を図5に示す. 同図より，騒音条件ごとに分布形状が大きく異なってい ることがわかる。

求めたIの確率分布と図1の回帰関数を用いて, (4) 式 


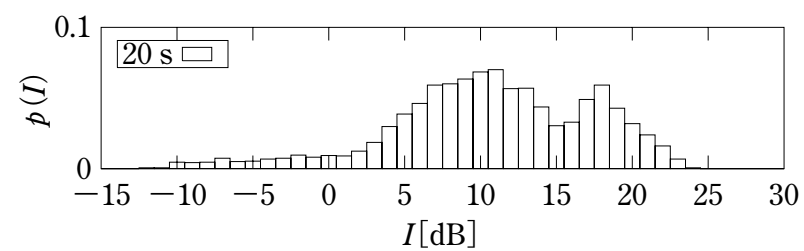

(a) Nonstationary road traffic noise $(62 \mathrm{~dB})$

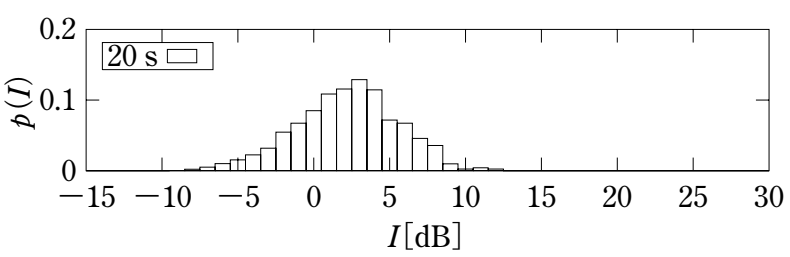

(b) Stationary road traffic noise $(62 \mathrm{~dB})$

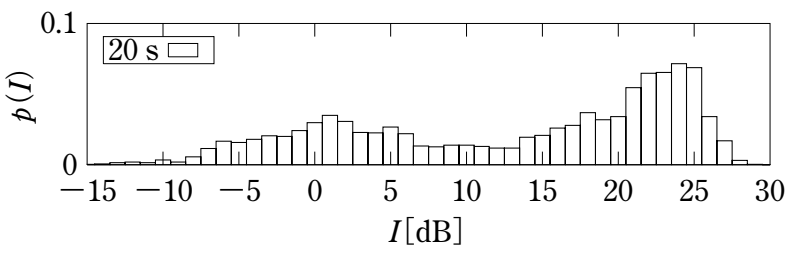

(c) Air plane noise $(62 \mathrm{~dB})$

\section{図5Iの確率分布（20歳代健聴者）}

Fig. 5 Probability distribution on $I(20 \mathrm{~s})$.

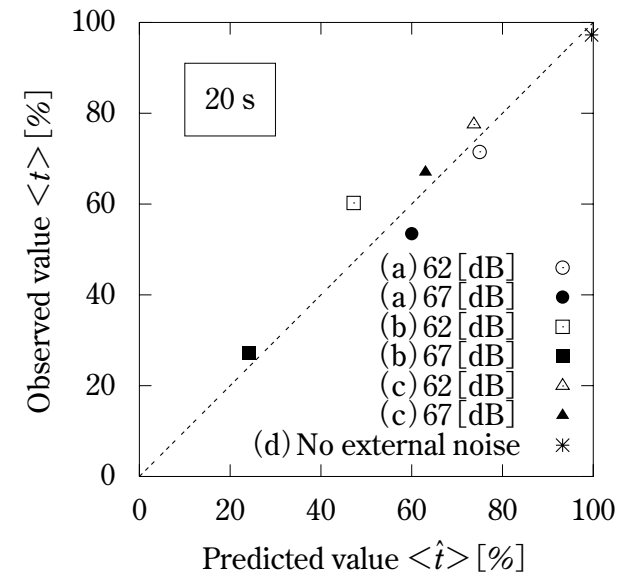

図6 音声聴取成績に対する予測值と実測值の比較（20歳代 健聴者）

Fig. 6 Comparison between predicted and observed value of $\langle t\rangle(20 \mathrm{~s})$.

により，騒音条件ごとに音声聴取成績の平均值を予測し て音声聴取心理実験で得られた実測值の平均値と比較し た。これらの結果を図6に示す。騒音条件（b） $(62 \mathrm{~dB})$ の場合に $10 \%$ 程度の䛊差がみられる以外，予測值は実測 值をほぼよく捉えていることがわかる，音声の聴き取り易 さの心理的印象に関しても，(5) 式により各騒音条件下に おける平均值を予測して, 実測值との比較を行った。 その 結果を図7に示す。いずれの騒音下においても予測值と実 測值の間にほぼ良い一致が認められる。

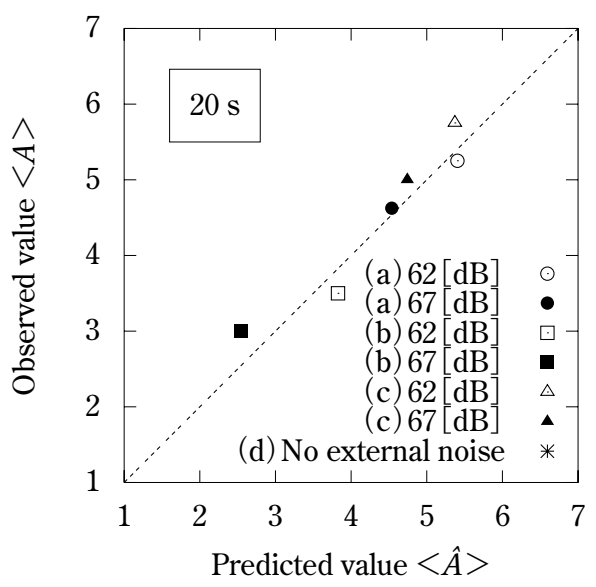

図7 音声の聴き取り易さの心理的印象に対する予測值と実 測值の比較（20歳代健聴者）

Fig. 7 Comparison between predicted and observed value of $\langle A\rangle(20 \mathrm{~s})$.

\section{4-2. 20 歳代健聴者を模擬難聴状態にした場合}

前節の 20 歳代健聴者の場合と同様に, $50,70,80$ 歳代 の加齢による聴力損失を模擬した周波数フィルタ $50 \mathrm{~s}$, $70 \mathrm{~s} ， 80 \mathrm{~s}$ に音声と騒音を通した場合についても，音源を 周波数分析し，(3) 式からIを算出してp (I) を求めた. $50 ， 70 ， 80$ 歳代の聴力損失を模擬した結果の例として， 騒音が (a)，(b)，(c)（いずれも62 dB）の場合を図8に 示す。いずれの騒音条件に扔いても，周波数フィルタ $50 \mathrm{~s}$, $70 \mathrm{~s}, 80 \mathrm{~s}$ の順に $p(I)$ の分布するIについての範囲が狭く なっていることがわかる.

上記で求めたIの確率分布と図 1 におけ $50 \mathrm{~s}, 70 \mathrm{~s}, 80 \mathrm{~s}$ の回帰関数を用いて (4) 式により，50，70，80歳代の加 齢による聴力損失を模擬した場合ごとに，各騒音条件下 での音声聴取成績の平均值を予測した。 $50 ， 70 ， 80$ 歳代 の聴力損失を模擬したそれぞれの場合において，音声聴 取心理実験で得られた実測值と比較した結果を図9に示す (同図には，周波数フィルタ $20 \mathrm{~s} ， 50 \mathrm{~s} ， 70 \mathrm{~s} ， 80 \mathrm{~s}$ 用い た全ての予測結果も併せて示した)． $50 \mathrm{~s} ， 70 \mathrm{~s} ， 80 \mathrm{~s}$ の 順に加齢に伴う聴力損失が大きくなるにしたがって，音 声聴取成績が低下する傾向がみられるが，その実測值の 傾向を予測值はほぼ良く捉えている。しかしながら $80 \mathrm{~s}$ の結果では，騒音なしの場合を除くいずれの騒音条件下 においても聴取成績の実測值が $20 \%$ 程度であることから， 他の異なる騒音条件について更に検討を加えることも予 測精度のより厳密な検証のために必要であろう。

同様に，音声の聴き取り易さに関する心理的印象に対 しても，図 2 の $50 \mathrm{~s} ， 70 \mathrm{~s} ， 80 \mathrm{~s}$ の回帰関数を用いて，(5) 式により $50 ， 70 ， 80$ 歳代の加齢による聴力損失を模擬し 

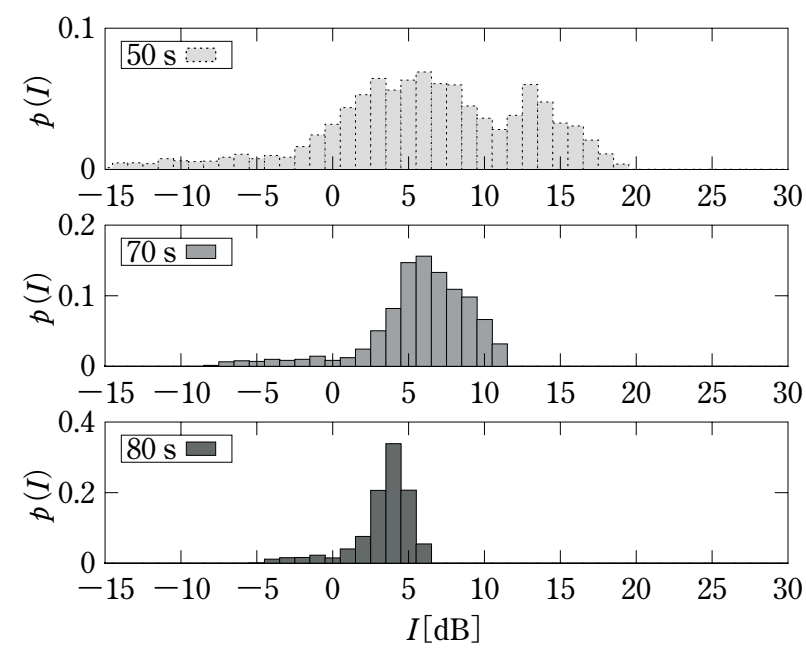

(a) Nonstationary road traffic noise $(62 \mathrm{~dB})$

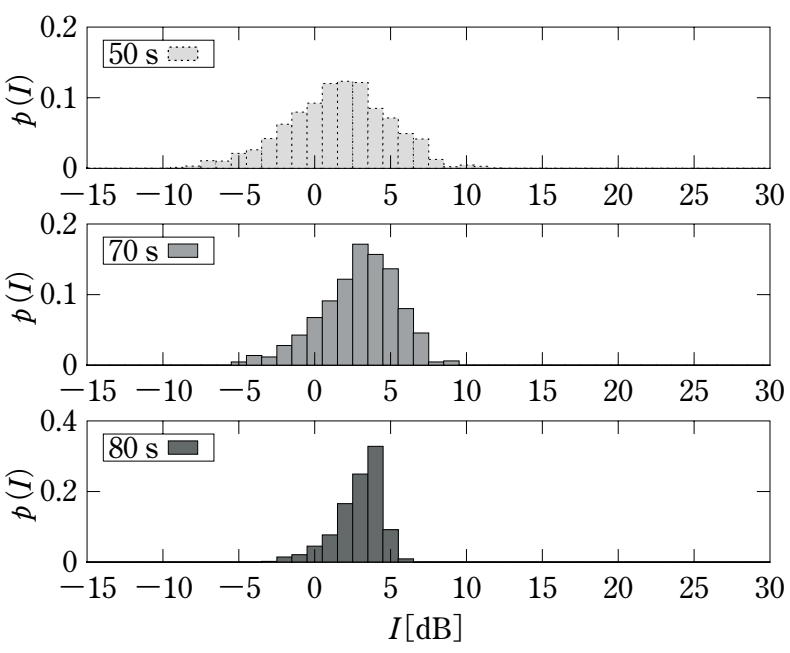

(b) Stationary road traffic noise $(62 \mathrm{~dB})$

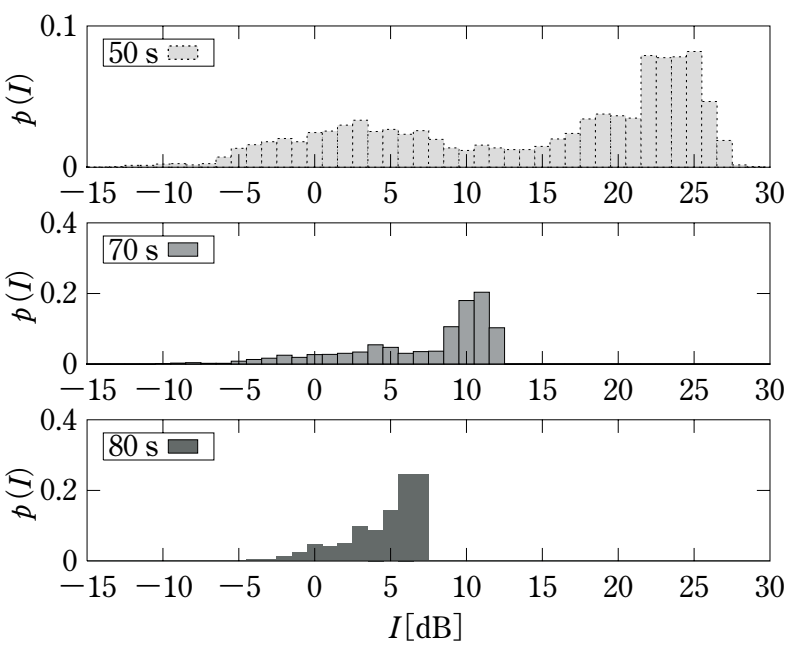

(c) Air plane noise $(62 \mathrm{~dB})$

図8Ｉの確率分布（模擬難聴状態）

Fig. 8 Probability distribution on $I(50 \mathrm{~s}, 70 \mathrm{~s}, 80 \mathrm{~s})$.

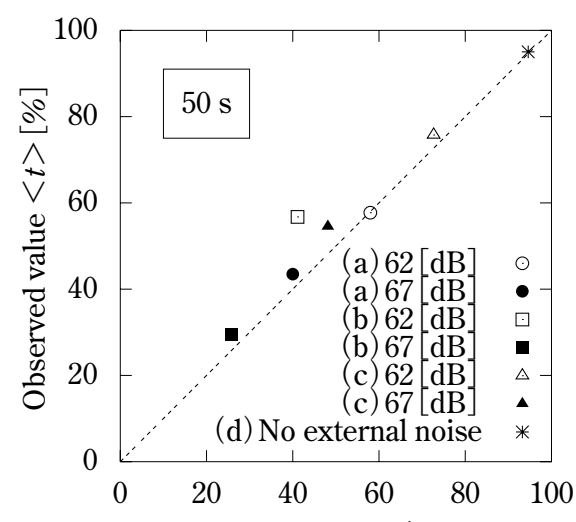

Predicted value $<\hat{t}>[\%]$
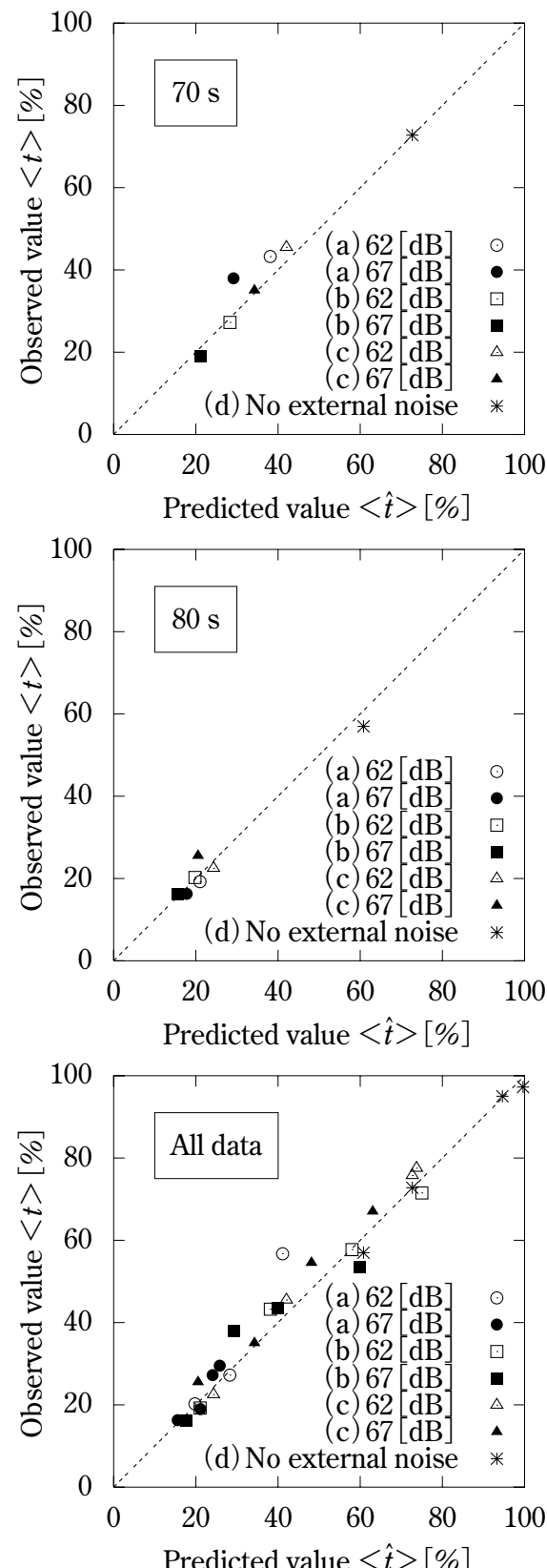

図9＼cjkstart音声聴取成績に対する予測值と実測值の比較

Fig. 9 Comparison between predicted and observed value of $<t>$. 

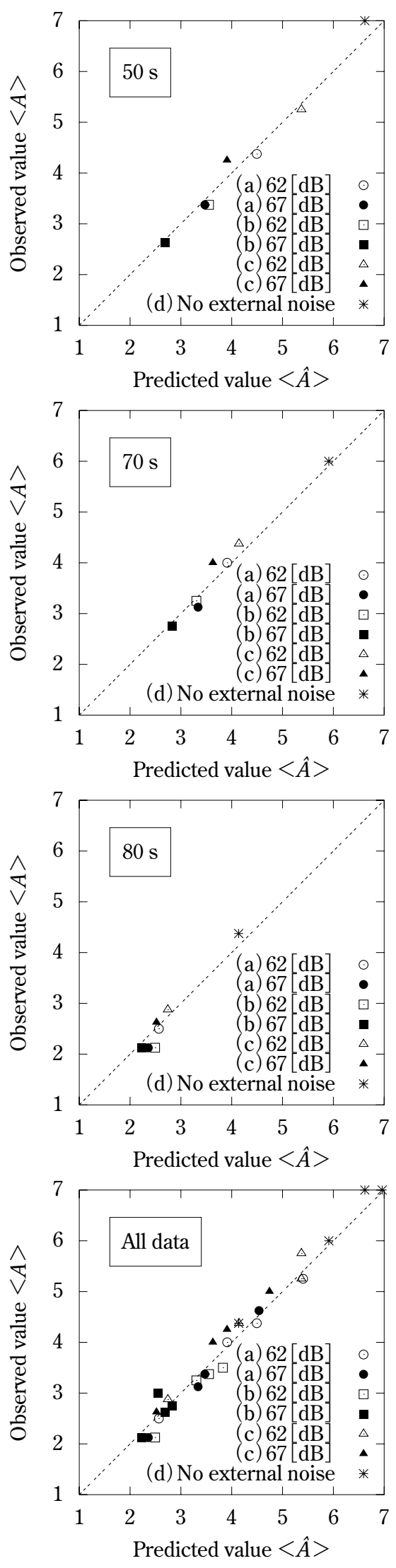

図10 音声の聴き取り易さの心理的印象に対する予測值と 実測值の比較

Fig. 10 Comparison between predicted and observed value of $\langle A\rangle$.
た場合の予測值を各騒音条件ごとに求めた。これらと実 測值との比較を行った結果を図10に示す（周波数フィル タ $20 \mathrm{~s} ， 50 \mathrm{~s} ， 70 \mathrm{~s} ， 80 \mathrm{~s}$ 用いた全ての予測結果も併せ て示している)。この場合も， $50 \mathrm{~s}, 70 \mathrm{~s}, 80 \mathrm{~s}$ の順に加 齢に伴って聴き取り易さの心理的印象が低下する傾向に あるが，いずれの騒音条件下においても予測值と実測值 の間のほぼ一致性が確認されたことから，本研究で提案 した予測手法の妥当性が認められる.

\section{5. まとめ}

本論文は，音声と騒音の振幅・周波数特性に関する相

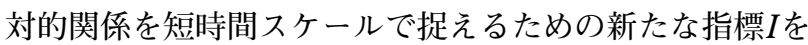
導入し，その確率密度関数を用いて，騒音の音圧レベル 值・周波数構成がともに時々刻々と不規則に変動する実 生活環境音場での音声聴取成績および音声の聴き取り易 さに関する心理的印象を，加齢による聴力損失特性を考 慮して予測するための一手法を提案した。具体的には， 加齢に伴う聴力損失特性を模擬した周波数フィルタを用 いて模擬難聴状態を実現し，20歳代の健聴者による音声 聴取心理実験を実施して得られた実測値と予測結果を比 較した。実験的確認に供したいくつかの具体例について 検討した結果，提案した手法の妥当性が確認された。

今後検討すべき主な問題点を列記すると次のようになる.

（1）本論文の結果は，周波数フィルタによって実現した 模擬難聴状態にある20歳代の健聴者によって得られ たものであるため，実際に聴力損失の現れている高 齢者等について考察すること，実際の聴力損失を有 する高齢者等から実測データを得ることができれば， 本研究の結果と比較することで模擬難聴状態にある 健聴者を実際に聴力損失を有する被験者として代用 することの是非を判断する際の重要な基礎的資料と なる。

（2）最小可聴值の上昇を模擬する他の方法としてマスキ ングノイズを用いる方法についても考察すること.

（3）最小可聴值の上昇のみでなく，周波数選択性や時間 分解能の低下およびラウドネス補充現象などの要因 についても考察すること。

（4）音声が単音節ではなく，単語や文章になった場合に ついても検討すること.

\section{謝 辞}

本研究に多大の援助をいただいた饗場恵治氏をはじめ, 日本音響学会研究発表会 ${ }^{28)}$ において有益なご討論をいた だいた各位に深謝の意を表する。 


\section{参考文献}

1）山口静馬, 為末隆弘, 佐伯徹郎, 加藤裕一：無意味外来 雑音下での音声聴取時における心理的評価と聴取成績に 関する一考察, 日本音響学会誌, 57 (6), 398-405, 2001.

2) 為末隆弘, 山口静馬, 佐伯徹郎, 加藤裕一: 無意味定常雑 音存在下での音声聴取時における心理的印象と聴取成績, 電子情報通信学会論文誌（A), J85-A (2), 258-265, 2002.

3) 為末隆弘, 山口静馬, 佐伯徹郎, 加藤裕一 : 音声聴取時 の無意味定常雑音に対する心理的応答と聴取成績, システ 么制御情報学会論文誌, 15 (7), 384-386, 2002.

4）為末隆弘, 山口静馬, 佐伯徹郎, 老松建成: 音声聴取時 の無意味定常雑音がうるささと聴取成績に及ぼす影響, 日 本音響学会誌, 58 (11), 704-710, 2002.

5) T. Tamesue, S. Yamaguchi, T. Saeki, Y. Kato : Psychological impression and listening score while listening to audio signal under meaningless steady noise, Applied Acoustics, 64 (4) , 443-457, 2003.

6) T. Tamesue, S. Yamaguchi, T. Saeki : Psychological impressions and listening score when listening to audio signals composed of monosyllables and words, while subject to meaningless steady noise - Introduction of weighted-mean spectral distance - : Journal of Sound and Vibration, 271 (3-5), 519-533, 2004.

7) K. D. Kryter : Methods for the calculation and use of the articulation index, Journal of Acoustical Society of America, 34, 1689-1697, 1962.

8）日本建築学会編：騒音の評価法 各種評価法の系譜と手 法, 148-157, 彰国社, 東京, 1981.

9) ISO7029. Threshold of hearing by air conduction as a function of age and sex for otologically normal persons 1984.

10）横内幸子：聴力の生理的年齢変化について, 日本耳鼻学 会誌, 67, 1307-1319, 1964.

11）中野有朋：入門 騒音工学, 114-116, 技術書院, 東京, 1999.

12）長友宗重, 佐藤洋：高齢社会における建築空間の音響設 計, 日本音響学会誌, 55 (12), 845-850, 1999.

13）樋渡涓二：視聴覚情報概論, 147-149, 昭晃堂, 東京, 1987.

14）佐藤洋：加齢による聴力低下が空間内における音声伝 達に及ぼす影響, 電子情報通信学会技術報告, TL2004-16, 25-30, 2004.

15）佐藤洋, 佐藤逸人, 吉野博, 鈴木陽一, 天野成昭, 近藤公 久, 長友宗重: 単語親密度と加齢による聴力損失が残響及 び騒音下に打ける単語了解度に及ぼす影響, 日本音響学会
誌, 58 (6) , 346-354, 2002.

16）佐藤逸人, 佐藤洋, 吉野博, 森本正之 : 加齢による聴力 損失が単語了解度及び「聴き取りにくさ」に与える影響, 日本建築学会大会学術講演梗概集, 23-24, 2001.

17）佐藤洋, 吉野博, 長友宗重, 佐藤冕人：若年層と高齢者 の単語了解度の比較一親密度を統制した単語リストを用 いた音声伝送性能評価に関する研究その 1 一, 日本建築学 会大会学術講演梗概集, 21-24, 2000.

18）大内孝子, 大川平一郎, 今岡雅行, 安岡正人, 子安勝：高 齢者の聴覚特性に対応する建築音環境計画に関する研 究一その 3 単音節明瞭度と単語扎よび文章了解度との関 係一, 日本建築学会大会学術講演梗概集, 31-32, 1999.

19）為末隆弘, 山口静馬, 佐伯徹郎：加齢等による聴力損失 が音声聴取成績および聴き取り易さの心理的印象に及ほ す影響, 人間工学, 41 (3), 131-136, 2005.

20）植松道治, 曽根敏夫, 二村忠元：ランダム変動騒音下の 音声明瞭度と了解度に関する基礎実験一変動騒音の言語 聴取妨害に関する研究その1一, 日本音響学会誌, 34 (9), 516-521, 1978.

21）曽根敏夫, 植松道治, 金指久則, 二村忠元：ランダム変動 騒音下の音声明瞭度の予測一変動騒音の言語聴取妨害に 関する研究その 2 - , 日本音響学会誌, 35 (2), 58-62, 1979 .

22）吉田拓正：変動騒音下における連続音声の了解性の評 定, 日本音響学会誌, 41 (7), 450-458, 1985

23） T. Tamesue, S. Yamaguchi, T. Saeki, Y. Kato : A method for prediction of listening score and psychological impression in an actual noise environment, Journal of Sound and Vibration, 287 (3), 625-636 (2005).

24）米本清：補聴器適合評価用CD (TY-89) の特徵, JOHNS, 11 (9), 1395-1401, 1995

25）稲生真, 豊島政実, 松岡輝雄, 我妻幾久寿, 宮地蓮生, 鷹 見淳一, 仮山周一：ホール電気音響設備調整用テスト CD について, 日本音響学会建築音響研究会資料, AA-86-40, 1986.

26）林哲也, 浅野太, 鈴木陽一, 曽根敏夫, 佐竹充章, 小林俊 光, 高坂知節 : マスキングノイズを用いた模擬難聴の聴覚 的特性に関する一考察, 日本音響学会聴覚研究会資料, H89-13, 1989.

27）中島立美, 前田節男：室内での音声の「聴き取り易さ」 とSTI, 日本音響学会建築音響研究会資料, AA84-30, 1-8, 1984.

28）為末隆弘，佐伯徹郎，伊東一典：加齢等による聴力損 失を考慮した聴取成績および心理的印象に対する一予測 手法, 日本音響学会 2007 年春季研究発表会講演論文集, 763-764, 2007. 